\title{
Bioclaustration in Devonian fenestrate bryozoans. The ichnogenus Caupokeras McKinney, 2009
}

\author{
Juan L. SUÁREZ ANDRÉS
}

SONINGEO, S.L. PCTCAN, P. 20, C/ Isabel Torres, 9. 39011 Santander, Cantabria, Spain; juanl_suarez@yahoo.es

Suárez Andrés, J.L. 2014. Bioclaustration in Devonian fenestrate bryozoans. The ichnogenus Caupokeras McKinney, 2009. [Bioclaustración en briozoos fenestrados devónicos. El icnogénero Caupokeras McKinney, 2009]. Spanish Journal of Palaeontology, 29 (1), 5-14.

\begin{abstract}
The ichnogenus Caupokeras is the only reported case of bioclaustration in which an symbiont is enveloped by fenestrate bryozoans. In this paper, type and additional material of Caupokeras from Belgium, Germany and Spain is revised and the number of bryozoan genera on which it occurs is expanded; a possible case from the Carboniferous of the USA is discussed and an expanded description of the ichnogenus and a palaeobiological interpretation are provided. The association between the fenestrate bryozoans and the sclerobionts that gave rise to this trace seems to have been more advantageous for the latter.
\end{abstract}

Keywords: Bryozoans, Devonian, trace fossils, palaeobiology, palaeoecology.

\section{RESUMEN}

El icnogénero Caupokeras es el único caso de bioclaustración conocido en el que un simbionte es enclaustrado por briozoos fenestrados. En el presente trabajo se revisa el material tipo y ejemplares adicionales de Caupokeras procedentes de Bélgica, Alemania y España, se discute un posible caso del Carbonífero de Estados Unidos y se amplía el número de géneros de briozoos sobre los que se desarrolla esta estructura; se aporta una descripción ampliada del icnogénero, así como una interpretación paleobiológica del mismo. La asociación entre los briozoos fenestrados y los epibiontes que dieron lugar a este icnofósil parece haber sido más beneficiosa para éstos últimos.

Palabras clave: Briozoos, Devónico, icnofósiles, paleobiología, paleoecología. 


\section{INTRODUCTION}

\subsection{Bioimmuration}

The term bioimmuration was created by Vialov (1961) to name the process and result of a species being preserved as a result of organic overgrowth. Bioimmuration is a common phenomenon among benthic communities, as species with different growth rates compete for a limited substrate, and it has been reported mostly on postpalaeozoic faunas. This process has an important role in the preservation of ecological relationships, and may become a source of information about organisms lacking mineralized skeletons, which otherwise are very rarely preserved in the fossil record. Some good examples of soft-bodied organisms preserved by bioimmuration have been provided by Taylor (1990a) and Wilson et al. (1994). Species lacking a mineralized skeleton may be preserved through traces of their activity, but these may not show accurate details of their anatomy. Traces exceptionally reflect the actual morphology of organisms; such is the case for boring ctenostome bryozoans which are known only as moulds, so they have been treated by some authors as trace fossils (Mayoral, 1991; Mayoral et al., 1994). Preservation of fossil encrusting ctenostomes by bioimmuration has allowed for the observation of fine-scale details of epizoic species that would have remained otherwise unknown (Taylor, 1990a, b).

\subsection{Bioclaustration}

Some peculiar interactions related to bioimmuration have been reported. Hayward \& Fordy (1982) described a case involving two living bryozoan species from South Africa; an erect host supports on its surface a delicate colony that grows rapidly and becomes gradually enveloped and eventually buried by the calcification of its host's frontal surface. Relations in which the epibiont is bioimmured alive by the host are possibly more frequent in fossil bryozoans than the literature may indicate (Suárez Andrés, 1999; Taylor \& Voigt, 2006; McKinney, 2009). The first reported case was described from the Ordovician by Palmer \& Wilson (1988), who defined the ichnogenus Catellocaula, a set of tubes developed inside massive zoaria of a trepostome bryozoan. These tubes are pseudoborings limited by a skeletal wall secreted by the bryozoan host, and the neighbouring chambers are deformed instead of cut by the symbiont. The authors concluded that a parasite settled on the surface of a living bryozoan colony and was enveloped by its subsequent growth. The infester was not killed, but kept growing with its living substrate.

With their description of Catellocaula, Palmer \& Wilson (1988) introduced the term bioclaustration for the action of embedding a soft-bodied infesting organism by a host with mineralized skeleton, and Taylor (1990a) expanded the concept to include skeleton-producing infesting organisms. Bioclaustration of commensals by tabulate corals is widely known; Fernández Martínez (1993) provided a historical review of this topic and reported ichnogenera present in Devonian tabulate corals from NW Spain. Ichnological and palaeoecological studies have been carried out by Tapanila (2002, 2005, 2006, 2008) and Tapanila \& Ekdale (2007). Jurassic and Cretaceous serpulid tubes from Europe commonly host bioclaustrated hydroids (Zágorsek et al., 2009). In contrast, references dealing with bryozoan hosts are very scarce, though bioclaustration structures can be found in the literature. For example, Cuffey (1967) mentioned and figured anomalous monticules in Tabulipora carbonaria (Worthen \& Meek, 1875), attributed to growth of the bryozoan colony around an epizoan. In other cases, traces were misinterpreted as distinctive characters of a new taxon; Dessilly \& Kräusel (1963) named the Devonian fenestrate genus Speotrypa for specimens with a set of tubes on the obverse surface. Revision of the type and additional material of Speotrypa couviniensis Dessilly \& Kräusel, 1963 by Suárez Andrés (1999) showed that all characters fit the diagnosis of Semicoscinium Prout, 1859, except for the tubular system developed on the superstructure, which was considered a distinctive character for the genus by the authors. Nevertheless, it must be rejected as a diagnostic character; Kräusel (1953) had figured similar tubes in his redescription of Cyclopelta Bornemann, 1884. Suárez Andrés (1999) reported identical structures in different genera from the Lower-Middle Devonian of NW Spain and interpreted the tubes as a trace due to the interaction between fenestrate bryozoans and a modular soft-bodied infesting organism. The author suggested the transference of Speotrypa couviniensis to Semicoscinium, subsequently corroborated by McKinney (2009), who named the new ichnogenus Caupokeras, designating as type specimens those of S. couviniensis in his study of bryozoan-hydroid symbiosis.

This paper is a contribution to our knowledge of Caupokeras, recording the fenestrate genera on which it developed, its geographical and stratigraphical distributions, and its palaeobiological interpretation.

\section{MATERIAL AND METHODS}

The holotype of Semicoscinium couviniensis (Dessilly \& Kräusel, 1963), ISRN 27250A-E, paratypes ISRN 27251, 27259 and 27260, and additional specimens ISRN 27267 and 27274 were studied when on behalf of a loan from the Institut Royal des Sciences Naturelles de Belgique, Brussels. Photographs of the neotype of Bigeyina winteri 
(Bornemann, 1884) SMF XVIII 303a and additional specimens SMF XVIII 304b, 305b, 305c, 307b, 307c, 307d, 307e, 307f, 308b housed at the Senckenberg Museum, Frankfurt am Main, were studied by Suárez Andrés \& McKinney (2010). Eleven specimens of fenestrates from Moniello Formation (Upper Emsian-Eifelian; Arnao, Asturias, NW Spain) showing Caupokeras tubes have been collected by the author, acetate peels have been made and deposited at the University of Oviedo (DGO 12812, 12817, 12831, 12837, 12838, 12839, 12857, 12858, 12868, 12869 and 12871). Photographs of the specimen of Hemitrypa proutana (Prout, 1859) NHMUK PI BZ D5750(a), housed at the Natural History Museum (London) have been kindly provided by Consuelo Sendino-Lara and Paul D. Taylor.

\section{SYSTEMATIC ICHNOLOGY}

\section{Ichnogenus Caupokeras McKinney, 2009}

Type species. Caupokeras calyptos McKinney, 2009.

Diagnosis. A network of distally expanded tubes, each giving rise near its distal end to a single or less frequently paired laterally budded descendant tubes bioimmured on the surface of a bryozoan colony by skeletal secretions of the bryozoan (after McKinney, 2009).

\section{Caupokeras calyptos McKinney, 2009}

(Figs 1, 2)

2009 Caupokeras calyptos McKinney, p. 200, Figs. 4 A-D.

Material. Eleven specimens; two on Hemitrypa (DGO 12812 and 12817); one on Quadrisemicoscinium (DGO 12831); three on Fenestrapora (DGO 12837, 12838, 12839); four on Bigeyina (DGO 12857, 12858, 12868 and 12869); one on Kalvariella (DGO 12871). Upper EmsianEifelian, Moniello Formation (Asturias, NW Spain).

Diagnosis. Gently curved bioimmured tubes about 2 $\mathrm{mm}$ long, about $0.15 \mathrm{~mm}$ diameter proximally to $0.5 \mathrm{~mm}$ distally (after McKinney, 2009).

Description. Tubes most commonly placed on the upper region of keels of high-keeled fenestrate bryozoans, occasionally on reverse surface of branches or directly on the obverse of low-keeled colonies. Tubes about $2 \mathrm{~mm}$ long, forming a gentle obtuse arc, with a narrow proximal end about $0.15 \mathrm{~mm}$ in diameter, widening towards the terminal aperture, about $0.5 \mathrm{~mm}$ in diameter. Tubes bud alternately right and left of parental tube; paired budding also occurs; the parental tube may be inflated at bifurcations and the terminal aperture be placed at the end of a short, tapered neck. Tubes are parallel or oblique to fenestrate branches, almost always pointing towards the growing edge of the bryozoan. Modified from McKinney (2009).

\section{REVISED OCCURRENCE AND EXPANDED DESCRIPTION OF CAUPOKERAS}

The type specimens of Caupokeras are preserved on colonies assigned to Semicoscinium from the Middle Devonian of Belgium, but this ichnogenus has also been found on other fenestrate genera from Germany and Spain. A description of the three sets of specimens follows, allowing for a more detailed understanding of morphology and an improved palaeobiological interpretation of this ichnogenus. A fenestrate species from the Carboniferous of US possibly hosted Caupokeras tubes too, as discussed below.

\subsection{The type specimens, Couvinian, Belgium}

The type specimens consist of a set of branching, gently curved tubes, with the same direction of growth as the fenestrate colony in which they are embedded. They are hosted by colonies of Semicoscinium, which have a high keel on the obverse surface. The tubes are always developed on the obverse of the bryozoan colony and cross the keel summits, being contained in a plane parallel to the underlying bryozoan meshwork; terminal apertures are placed between neighbouring keels, hanging over the autozooecial apertures of the host and contained in the plane of the bryozoan surface defined by the keel summits. Keels appear lowered in front of the terminal apertures of Caupokeras; the resulting gaps can be clearly appreciated in tangential sections (Fig. 1a). Laminated skeleton secreted by the bryozoan host, which becomes heavily thickened in some places, forms the walls of the tubes.

\subsection{Specimens on Bigeyina, Eifelian, Germany}

Tubular structures later assigned to Caupokeras were figured by Kräusel (1953, pl. 1, figs. 2c, 7; pl. 2 figs. 8a, 11) in his redescription of the Devonian semicosciniid Cyclopelta on the basis of newly collected material from Eifel, Germany, after the loss of the original type specimen. Suárez Andrés \& McKinney (2010) revised this genus and provided a detailed diagnosis and description, in which they mentioned the occasional presence of Caupokeras. The tubes are developed on the characteristic laths present on the tops of the keels; their distribution is similar to that of the Belgian material. The laminar walls of the tubes 

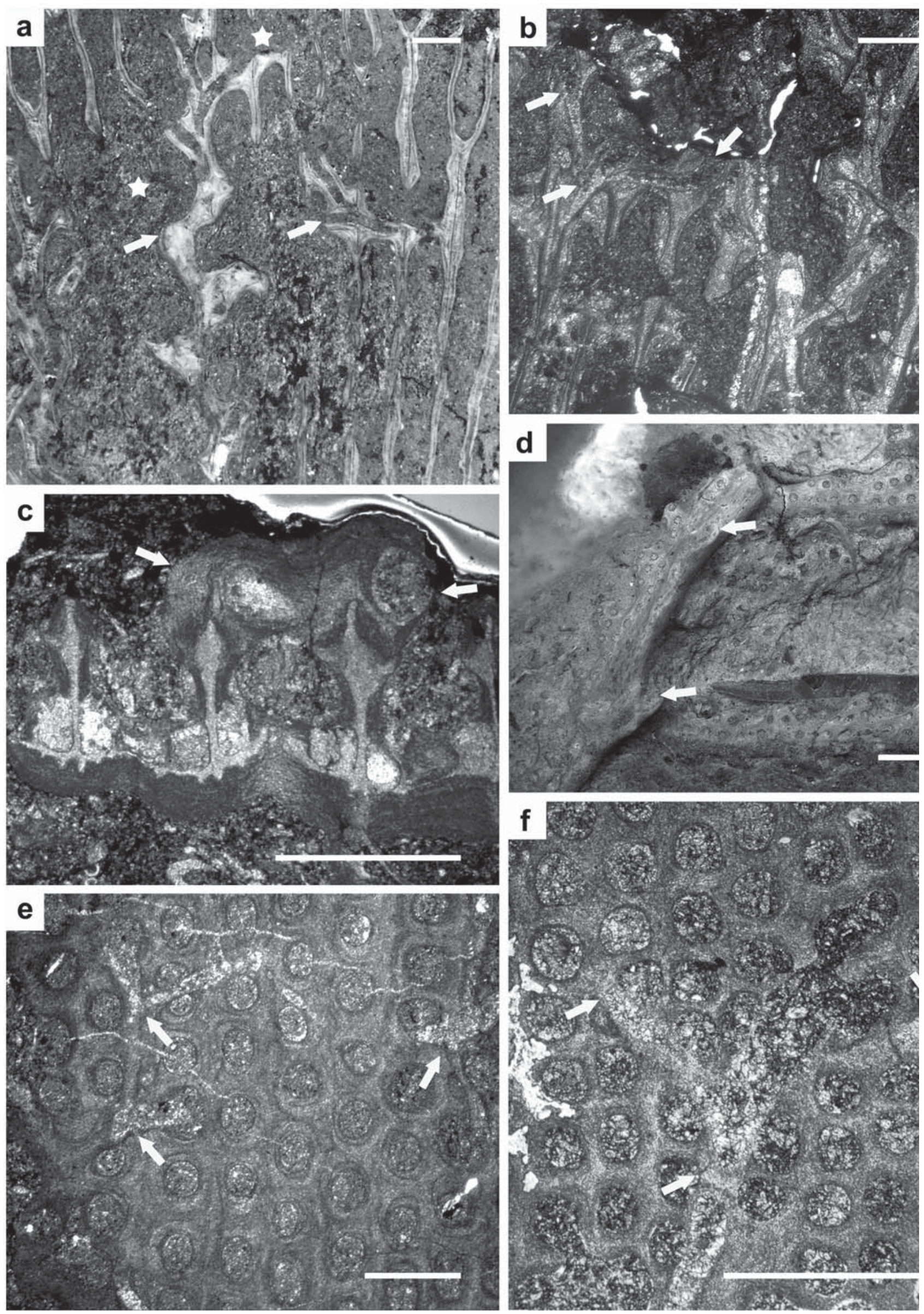
secreted by the host become heavily thickened and gaps in front of terminal apertures also exist, resulting in extreme distortion of the original "Y"-shaped morphology of keels.

\subsection{Specimens from the Lower-Middle Devonian of NW Spain}

The Lower-Middle Devonian Moniello Formation (Asturias, NW Spain) has yielded specimens of Caupokeras developed on different genera, some of them showing novel features not observed in specimens from Belgium and Germany. Suárez Andrés (1999) reported the presence of anomalous tubular structures in specimens of Semicoscinium, Hemitrypa and Bigeyina, comparing them with those figured and described by Dessilly \& Kräusel (1963) and Kräusel (1953). Subsequent systematic work by the author has revealed that the specimens of Semicoscinium really belong to Quadrisemicoscinium Plamenskaja, 1991 and Fenestrapora Hall, 1885. Hemitrypa Phillips, 1841 is the only host in which Caupokeras has been observed to occur both on the obverse and on the reverse surface, always keeping the same aspect. This fact is possibly due to the position of the obverse on the inner surface of the colonies, as will be discussed further on. The traces present on the obverse surface may be somewhat obscured by the honeycomb-shaped superstructure of this genus; tubes on the reverse surface of branches have been found in old zoaria with thick deposits of laminar skeleton. Bigeyina is a relatively common host to Caupokeras; wide conical zoaria were infested, as proved by large fragments covered with these structures, while no evidence of the trace has been found on narrow, tubular zoaria.

Kalvariella Morozova, 1970 is a very rare acanthocladiid fenestrate present in the Lower-Middle Devonian Moniello Formation, which is the earliest occurrence for this genus. Acanthocladiids have very low keels or lack them; one of the specimens of Kalvariella that has been identified from the Moniello Formation shows well developed tubes on the obverse that can be assigned to Caupokeras, constituting the first reported case of this ichnogenus occurring on a low keeled fenestrate. Kalvariella is not reticulate but pinnate, so lateral expansion of tubes is severely restricted; terminal apertures are slightly twisted outwards instead of contained in a plane parallel to the bryozoan surface. Tubes are placed directly over inactive, sealed zooecial apertures of this old colony.

Additionally to the specimens from Asturias described herein, Ernst (2012) reported the presence of Caupokeras on the obverse of Bigeyina aff. sacculus from the Lower Devonian (Emsian) of León. Among the regions in which Caupokeras has been found, the Lower-Middle Devonian of NW Spain shows the widest diversity of bryozoan hosts.

\subsection{Specimens from the Lower Carboniferous of the USA}

Ulrich (1890) described Hemitrypa proutana var. vermifera as a variety of the species $H$. proutana (Prout, 1859) represented by a number of specimens from the Lower Carboniferous of Illinois with "certain peculiar, tubular, vermiform bodies, which are irregularly distributed over and form part of the reverse face of the zoarium. They are about $2 \mathrm{~mm}$ long and $0.5 \mathrm{~mm}$ in diameter, lie more or less nearly parallel with the branches, and have a subcircular opening at the distal extremity." This description is very similar to that of Caupokeras occurring on the reverse surface of Hemitrypa from the Devonian of NW Spain, although Snyder (1991) interpreted the tubes as support structures and transformed Ulrich's variety into an independent species, $H$. vermifera. The weathered reverse surface of a specimen of Hemitrypa proutana (NHMUK PI BZ D5750(a)) from the Warsaw Beds of Warsaw, Illinois, shows crushed roofs of tubular structures that can be tentatively identified as Caupokeras calyptos (Fig. $2 b)$. Consequently, though the identification is equivocal, this can be considered the only reported occurrence of the ichnogenus outside the Lower-Middle Devonian of Europe.

\subsection{Expanded description of Caupokeras McKinney, 2009}

As observed in the specimens and localities mentioned above, the trace is a system of smooth, curved tubes commonly occurring on the superstructure of fenestrate bryozoans, contained in a plane parallel to and placed above that of the host surface. It is rarely present on the reverse surface of Hemitrypa and exceptionally on the

Figure 1. Caupokeras calyptos McKinney, 2009. a) Tangential section of Semicoscinium couviniensis (Dessilly \& Kräusel, 1963) with alternating tubes parallel to the underlying branches of the host (arrows). Gaps in the bryozoan keels around the trace are evident (stars; paratype ISRN 27251A). b-f) Specimens from the Upper Emsian, Moniello Formation (Arnao, Asturias, NW Spain); (b) tangential section of Bigeyina sp. showing terminal and lateral paired tubes (arrows) on top of abnormally grown keels, DGO 12857; (c) transverse section of Quadrisemicoscinium discretum showing anomalous thickening of keels (arrows) affected by tubes, DGO 12831; (d) obverse view of an old zoarium of Kalvariella sp. with alternating tubes (arrows) of Caupokeras; DGO 12871; (e) tangential section of Hemitrypa sp. with symbiont tubes (arrows) hosted in the reverse surface of branches; DGO 12812; (f) detail of a terminal tube with paired descendants (arrows) formed on the superstructure of Hemitrypa sp., DGO 12817. Scale bar: $1 \mathrm{~mm}$. 
obverse of fenestrate bryozoans lacking high keels or more complicated superstructures such as Kalvariella.

Tubes are circular in cross section, about $0.15 \mathrm{~mm}$ in diameter at their proximal end and widening towards the terminal apertures, which reach up to $0.5 \mathrm{~mm}$ in diameter. From each tube, one or two lateral ones arise near the aperture; when new tubes are generated one by one, their position is alternating (Fig. 1a). Paired descendant tubes occur in opposite positions (Figs 1b, f) and may give place to bifurcations. The symbiont grew in the same direction as the host; a single trace can show sequences of alternating tubes that run parallel to the host branches (Fig. 1a) and areas of lateral expansion in which the bilateral pattern is more frequent (Fig. 1f). Tubes intersect obliquely the bryozoan keels and eventually open between two of them, their terminal apertures hanging over the apertures of the hosts without touching them (Fig. 1c). Normal growth of the host is interrupted in front of the terminal apertures of the symbiont; gaps due to abnormally reduced growth of superstructures can be clearly observed (Figs 1a-b). Tubes on the reverse of Hemitrypa are contained in the plane of the host branches and tube apertures are placed in fenestrules, voids of the host reticulate meshwork (Figs 1e, $2 \mathrm{~b})$. In the only known case of Caupokeras developed on a low-keeled bryozoan, tubes run on the obverse between zooidal apertures with their distal end twisted outwards instead of flat with the rest of the structure (Fig. 1d).

Thin sections and acetate peels of Caupokeras reveal that the laminated wall of the tubes is continuous with the microstructure of the laminar skeleton of the bryozoan host (Fig. 2a); no skeletal remains attributable to the bioclaustrated symbiont have been observed inside the tubes.

\section{PAlAEOBIOLOGICAL INTERPRETATION OF CAUPOKERAS}

Bioclaustration is a particular type of bioimmuration in which an infester and a living biological substrate interact to produce an embedment trace fossil. The term bioclaustration was introduced by Palmer \& Wilson (1988) and the concept developed by later authors (Taylor, 1990a; Tapanila, 2002, 2005, 2008; Tapanila \& Ekdale, 2007; McKinney, 2009). Many cases of bioclaustration correspond to cnidarian hosts and endosymbionts that lived between the corallites; in contrast, Catellocaula and Caupokeras are hosted by Palaeozoic bryozoans.

Caupokeras is the result of the interaction between a fenestrate bryozoan host and a soft-bodied organism that provoked the secretion of calcified skeleton by the bryozoan colony around the infester. McKinney (2009) attributed the trace to a hydroid, regarding its dimensions and morphology as those of recent haleciids, and supported by studies on recent faunas that have evidenced widespread relations between bryozoans and epizoic hydroids (Hastings 1930, 1945; Gautier, 1962). Hydroids of the family Zancleidae are known to be symbiotic with bryozoans, most commonly as epibionts on encrusting species; the bryozoan hosts encase the epizoic hydroids, a reaction providing the latter with a calcified covering. Recent associations of bryozoans and hydroids range from parasitism to commensalism and mutualism. Gautier (1962) suggested that the hydroids take advantage of the currents generated by the bryozoans, as they are passive suspension feeders. McKinney (2009) cited cases of interference of feeding hydroids with normal filtering
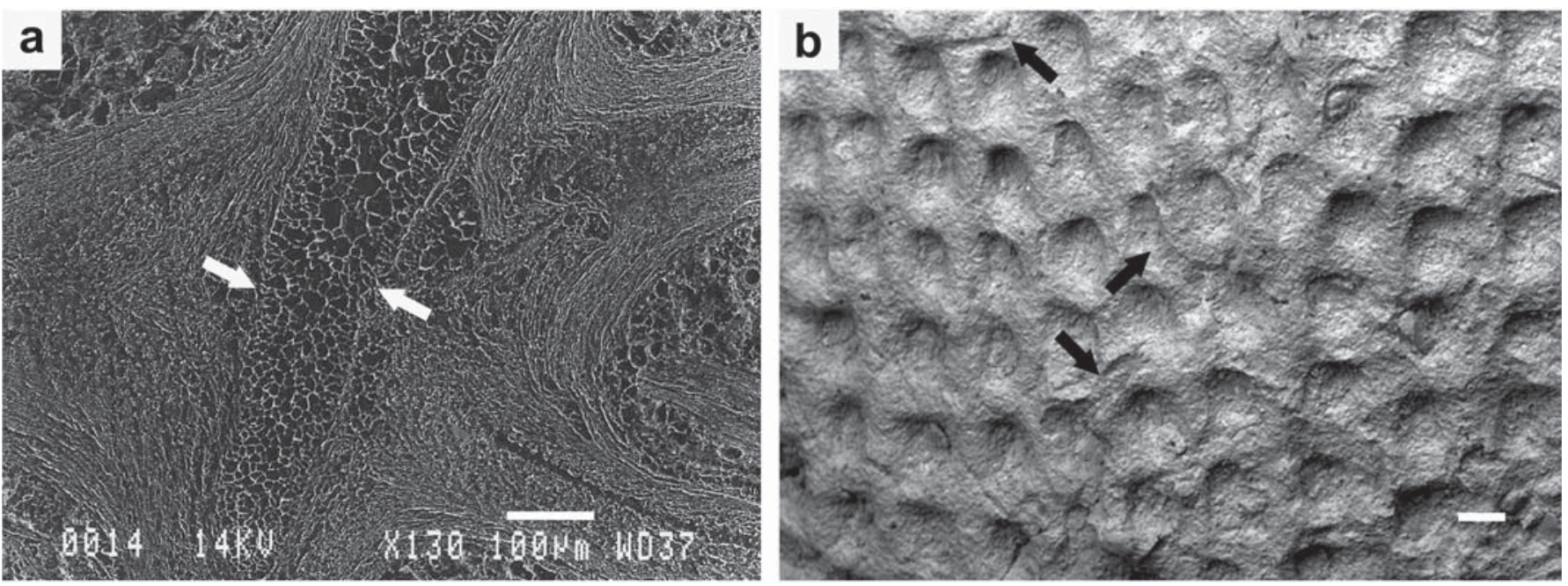

Figure 2. Caupokeras calyptos McKinney, 2009. a) SEM image of an acetate peel of Quadrisemicoscinium discretum showing a tangential section of a keel intersected by a tube (arrows), DGO 12831, Upper Emsian, Moniello Formation (Arnao, Asturias, NW Spain). b) Reverse surface of Hemitrypa proutana (Prout, 1859) with weathered tubular structures (arrows) tentatively identified as Caupokeras. NHMUK PI BZ D5750 (a), Carboniferous, Warsaw Beds (Warsaw, Illinois, USA). Scale bar: $0.2 \mathrm{~mm}$. 
function and occasional predation on the host tentacles. On the other hand, Osman \& Haugsness (1981) reported cases of bryozoan colonies with epizoic hydroids being more successful in competition for substrate and more resistent to predation than those of the same species lacking bioclaustrated epibionts. The kind of relation between the epibiont and the bryozoan host that gave place to Caupokeras is difficult to assess, because benefits to the host cannot be clearly demonstrated. Some points regarding the interaction between the epibiont and its host are discussed below.

\subsection{Secretion of skeletal material}

Recent epizoic hydroids living in association with bryozoans are usually small when compared to their hosts, so the skeleton secreted by the latter is commonly thin and consequently, not a significant additional expense. In Caupokeras, the inner section of the tubes is wider than the zooecia placed below, and the laminar skeleton secreted around the epibiont may also grow thicker than the bryozoan chamber width (Fig. 1c). Even though the fenestrate genera identified as hosts for Caupokeras have well developed extrazooidal parts and achieve remarkable astogenetic thickenings of the laminar wall, it should be assumed that bioclaustration of the epibiont, which clearly benefited from the mineralized covering, represented a costly response for the bryozoan colonies.

\subsection{Position of the tubes}

Caupokeras tubes developed on conical colonies of Semicoscinium, Quadrisemicoscinium, Fenestrapora and Bigeyina are placed on the obverse surface, developing on the upper part of the superstructure, with apertures hanging over the zooids (Fig. 1c). No evident damage to zooecial apertures placed under the tubes has been observed. Regarding the pattern of water currents generated by reticulate bryozoans (Cowen \& Rider, 1972; Cook, 1977), the epibiont would have benefited by feeding on the incoming currents generated by the underlying zooids, which must have received a partially depleted flow of nutrients. This argument was used by Suárez Andrés (1999) to interpret the epibiont as parasitic; nevertheless, occurrence of large fragments of fenestrates showing Caupokeras indicates that the bryozoan colonies were able to grow and age infested. No traces have been observed on narrow tubular individual or branching cones of Bigeyina ibera; old colonies of this species show extensive deposits of vesicular tissue sealing zooecia and fenestrules and enveloping the superstructure, leaving only a reduced active feeding zone. This fact may have limited or prevented settlement of the symbiont in colonies with such morphologies. The only specimen of Kalvariella having symbiont tubes shows a variation on this general scheme adapted to low-keeled pinnate hosts, with the structure supported on the obverse of the wide main stem. Unlike all the other host genera, the tubes developed by Kalvariella occur in a relatively basal region of the colony in which zooecial apertures were sealed by laminar skeleton prior to the settlement of the symbiont. In this case, and due to the morphology of the bryozoan colony, the host provides a very limited space for settlement and growth of the symbiont in comparison with reticulate bryozoans with a superstructure (Fig. 1d).

Only one species of Hemitrypa from the Devonian of NW Spain is known to bear Caupokeras tubes. This is a new species currently under study, and it is the only one known in the genus to have apertures on the inner surface of the cone. Among the fenestrate genera reported as hosts to Caupokeras, Hemitrypa is the one with the most elaborated superstructure and the only one in which tubes occur both on the obverse and reverse surfaces (Figs 1ef). The honeycomb-shaped protective meshwork probably prevented settlement and growth of symbionts, which should have settled in places where the superstructure is only incipent, that is, in growing edges of the host. Furthermore, the placement of the bryozoan apertures on the inner surface of the conical colony may have rendered the reverse surface of branches an advantageous place for settlement, as they are more exposed to environmental currents than those of Semicoscinium, Quadrisemicoscinium, Fenestrapora and Bigeyina.

The observed diversity of hosts and associated trace patterns indicate that the symbiont possibly settled on different substrates but succeeded growing and getting bioclaustrated only in some of them.

\subsection{Protection against predators}

In mutualistic associations between encrusting bryozoans and hydroids, these are known to benefit the former with the protection of their nematocysts, thus improving their chances in competition for space and defence against predators. This may have been the case for the organism that originated Caupokeras, but it cannot be demonstrated. Fenestrate bryozoans are erect forms not encrusting, and the influence of the simbiont on their capability in competition for substrate is difficult to assess, even more when they are often found as fragments due to a combination of sedimentary and diagenetic processes. Predation on Palaeozoic fenestrates is little known; small predators that may have fed on the soft tissues may probably have been repelled by the hydroid. The fact that fenestrate fragments bearing Caupokeras commonly correspond to old colonies, as evidenced by astogenetic thickening of their laminar skeletons, may point to a positive effect of the symbiont on the host, though all the Caupokeras-bearing species 
certainly were able to live without the symbiont, so the association was probably more advantageous for the latter than for the bryozoans.

\section{CONCLUSIONS}

The ichnogenus Caupokeras McKinney, 2009 is the result of bioclaustration of a soft-bodied epibiont, probably a hydroid, by fenestrate bryozoans. The reported stratigraphical range is Emsian-Eifelian (Lower-Middle Devonian) and the geographical distribution comprises Western Europe, though it was probably present also in the Carboniferous of USA.

The number of fenestrate genera on which the trace occurs is here expanded to six: Semicoscinium, Quadrisemicoscinium, Fenestrapora, Bigeyina, Hemitrypa and Kalvariella. The Emsian-Eifelian Moniello Formation (Asturias, NW Spain) bears the greatest diversity of reported host genera, with all but Semicoscinium being present.

Only in Hemitrypa can the trace be found both on the obverse superstructure and on the reverse surface of branches, possibly due to the position of the zooecial apertures on the inner surface of the conical colonies, inverted with respect to the other reticulate genera. Alternatively, the location on the reverse of branches may be the result of the exploitation of a new suitable place for settlement, the superstructure of Hemitrypa being too tight to allow for normal development of the symbiont.

Pinnate bryozoans such as Kalvariella were less advantageous hosts, as they lack wide surfaces available for settlement and growth of the symbiont, which rarely succeeded in being bioclaustrated. The symbiont possibly settled on a wider range of substrates but succeeded growing and getting bioclaustrated only in some of them.

Caupokeras would be best classified within impedichnia, according to Tapanila (2005), due to the alterations of the normal growth of the bryozoan colonies caused by this symbiont. With our present knowledge, symbionts that caused Caupokeras cannot be clearly interpreted as parasitic, but the association with fenestrate bryozoans may have been more profitable for them than for their hosts.

\section{ACKNOWLEDGEMENTS}

This study benefited from discussion with the late Ken McKinney. The Institut Royal des Sciences Naturelles de Belgique is thanked for the loan of type and additional material of Semicoscinium couviniensis. Consuelo Sendino-Lara and Paul D. Taylor (Natural History
Museum, London) are thanked for photographs of Hemitrypa proutana. This research received support from the SYNTHESYS Project http://www.synthesys.info/ which is financed by European Community Research Infrastructure Action under the FP7 "Capacities" Program, through a grant awarded to J.S. in 2012 (GB-TAF 2129) to visit the NHM (London). Esperanza Fernández-Martínez (University of León) and Paul D. Taylor are thanked for their helpful, constructive reviews.

\section{REFERENCES}

Bornemann, J.G. 1884. Cyclopelta winteri, eine Bryozoe aus dem Eifeler Mitteldevon. Zeitschrift der Deutschen Geologischen Gessellschaft, 36, 864-865.

Cook, P.L. 1977. Colony-wide water currents in living Bryozoa. Cahiers de Biologie Marine, 18, 31-47.

Cowen, R. \& Rider, J. 1972. Functional analysis of fenestellid bryozoan colonies. Lethaia, 5, 145-164.

Cuffey, R.J. 1967. Bryozoan Tabulipora carbonaria in Wreford Megacyclothem (Lower Permian) of Kansas. The University of Kansas Paleontological Contributions, Bryozoa Article, 1, 1-96.

Dessilly, E. \& Kräusel, W. 1963. Les Bryozoaires Devoniens de la Belgique. Speotrypa, nouveau genre du Couvinien de la Belgique. Bulletin Institut royal des Sciences Naturelles de Belgique, 39, 1-13.

Ernst, A. 2012. Fenestrate bryozoan fauna of the Lower - Middle Devonian of NW Spain. Neues Jahrbuch für Geologie und Paläontologie. Abhandlungen, 264, 205247.

Fernández Martínez, E. 1993. Tabulados y Chaetétidos de las Formaciones Moniello-Santa Lucía y Candás-Portilla (Devónico, Cordillera Cantábrica, NO de España). PhD Thesis, Universidad de Oviedo.

Gautier, Y.V. 1962. Recherches ecologiques sur les bryozoaires chilostomes en Mediterranée occidentale. Recueil des Travaux de la Station Marine d'Endoume Bulletin, 24, 1-434.

Hall, J. 1885. Bryozoans of the Hamilton Group. Report of the State geologist for the year 1883. Weeds, Parsons \& Co., Albany, 5-61.

Hastings, A.B. 1930. On the association of a gymnoblastic hydroid (Zanclea protecta, sp. n.) with various cheilostomatous Polyzoa from the Tropical E. Pacific. Annals and Magazine of Natural History, 10, 552-560.

Hastings, A.B. 1945. The Polyzoa, with a note on an associated hydroid. Great Barrier Reef Expedition 19281929, IV, 12, 50-454.

Hayward, P.J. \& Fordy, M.R. 1982. A new species of bryozoan epizooite from South Africa. Journal of Natural History, 16, 769-773.

Kräusel, W. 1953. Cyclopelta winteri (Bryozoa) aus dem Mittel-Devon der Eifel. Senckenbergiana, 34, 43-52.

Mayoral, E. 1991. Actividad bioerosiva de briozoos 
ctenostomados en el Ordovícico Superior de la Zona Cantábrica del Macizo Hespérico (Cabo Vidrias, Oviedo). Revista Española de Paleontología, 6, 27-36.

Mayoral, E., Gutiérrez Marco, J.C. \& Martinell, J. 1994. Primeras evidencias de briozoos perforantes (Ctenostomata) en braquiópodos ordovícicos de los Montes de Toledo (Zona Centroibérica Meridional, España). Revista Española de Paleontología, 9, 185-194.

McKinney, F.K. 2009. Bryozoan-Hydroid symbiosis and a new ichnogenus, Caupokeras. Ichnos, 16, 193-201.

Morozova, I.P. 1970. Mshanki Pozdney Permi. Nauka, Trudy Pal. Inst. N. Akademyi Nauk SSSR, 222, 1-347.

Osman, R.W. \& Haugsness, J.A. 1981. Mutualism among sessile invertebrates: a mediator of competition and predation. Science, 211, 846-848.

Palmer, T.J. \& Wilson, M.A. 1988. Parasitism of Ordocivian bryozoans and the origin of pseudoborings. Palaeontology, 31, 939-949.

Plamenskaja, A. 1991. Mshanki nijnego i srednego devona Kazajstana. In: Biostratigrafia Nijnego i Srednego Devona Djulgaro-Baljashkoy provintsii (eds Dubatolov, V.N. \& Stukalina, G.A.). Akademiya Nauk SSSR, Sibirskoe Otd., Novosibirsk, 91-111.

Phillips, J. 1841. Bryozoa. Figures and descriptions of the Palaeozoic fossils of Cornwall, Devon and West Somerset, $12,20-27$

Prout, H. 1859. Third series of descriptions of Bryozoa from the Paleozoic rocks of western states and territories. Transactions of St Louis Academy of Sciences, I, 443-452.

Snyder, E.M. 1991. Revised taxonomic procedures and paleoecologic applications for some North American Fenestellidae and Polyporidae (Bryozoa). Paleontographica Americana, 57, 1-275.

Suárez Andrés, J.L. 1999. Parasitismo en briozoos devónicos de la Zona Cantábrica. Temas Geológico-Mineros ITGE, 26, 647-650.

Suárez Andrés, J.L. \& McKinney, F.K. 2010. Revision of the Devonian Fenestrate bryozoan genera Cyclopelta Bornemann, 1884 and Pseudoisotrypa Prantl, 1932, with description of a rare growth habit. Revista Española de Paleontología, 25, 123-138.

Tapanila, L. 2002. A new endosymbiont in Late Ordovician tabulate corals from Anticosti Island, Eastern Canada. Ichnos, 9, 5-22.
Tapanila, L. 2005. Palaeoecology and diversity of endosymbionts in Palaeozoic marine invertebrates: Trace fossil evidence. Lethaia, 38, 89-99.

Tapanila, L. 2006. Macroborings and bioclaustrations in a Late Devonian reef above the Alamo Impact Breccia, Nevada, USA. Ichnos, 13, 129-134.

Tapanila, L. 2008. Direct evidence of ancient symbiosis using trace fossils. In: From evolution to geobiology: research questions driving Paleontology at the start of a new century (eds. Kelley, P.H. \& Bambah, R.K.). Paleontological Society Short Course, Paleontological Society Papers, 14, 271-287.

Tapanila, L. \& Ekdale, A.A. 2007. Early history of symbiosis in living substrates: trace-fossil evidence from the marine record. In: Trace fossils: concepts, problems, prospects (ed. Miller, W.). Elsevier, Amsterdam, 345-355.

Taylor, P.D. 1990a. Preservation of soft-bodied and other organisms by bioimmuration - a review. Palaeontology, $33,1-17$.

Taylor, P.D. 1990b. Bioimmured ctenostomates from the Jurassic and the origin of cheilostome Bryozoa. Palaeontology, 33, 19-34.

Taylor, P.D. \& Voigt, E. 2006. Symbiont bioclaustrations in Cretaceous cyclostome bryozoans. In: Contributions to bryozoology: a tribute to Ehrhard Voight (1905-2004) (eds Scholz, J., Taylor, P.D. \& Vávra, N.), Courier Forschunginstitut Senckenberg, 257, 131-136.

Ulrich, E.O. 1890. Palaeozoic Bryozoa. Illinois Geological Survey Bulletin, 8, 283-688.

Vialov, O.S. 1961. Phenomena of vital immuration in nature. Dopovidi Akademi Nauk Ukrayin'skoi RSR, 11, 15101512.

Wilson, M.A., Palmer, T.J. \& Taylor, P.D. 1994. Earliest preservation of soft-bodied fossils by epibiont bioimmuration: Upper Ordovician of Kentucky. Lethaia, 27, 269-270.

Worthen, A.H. \& Meek, F.B. 1875. Description of invertebrates. Geological Survey of Illinois, 6, 489-532.

Zágorsek, K., Taylor, P.D. \& Vodrázka, R. 2009. Coexistence of symbiotic hydroids (Protulophila) on serpulids and bryozoans in a cryptic habitat at Chrtníky (Lower Turonian, Czech Republic). Bulletin of Geosciences, 84, 631-636. 
